\title{
Impact of Front Line Demonstration on Soybean in Hingoli District of Maharashtra, India
}

\author{
R.T. Bhowate*, M.B. Dhole and A.P. Olambe \\ Krishi Vigyan Kendra Tondapur, Dist. Hingoli, Maharashtra, India \\ *Corresponding author
}

\section{Keywords}

Front line demonstration, Soybean, B:C ratio.

Article Info

Accepted:

28 August 2017

Available Online:

10 September 2017

\section{A B S T R A C T}

Front line demonstration on soybean were organized for five years in kharif seasons of 2009-2012 and 2013-2015 in six adopted villages namely Dandegaon, Kumbharwadi, Digras, Sukalivir, yedsi and Bhategaon of Kalamnuri Taluka by Krishi Vigyan Kendra, Tondapur, District Hingoli in Maharashtra. The package of improved practices demonstrated, which included a new variety MAUS 71, balance fertilizer (soil test based) viz., 30:60:30 + 30 Kg Zinc Sulphate kg/ha + Rhizobium + PSB @ $25 \mathrm{~g} / \mathrm{kg}$ seed over existing farmers practices of (local check18:46:00:00 NPKS kg/ha). Sixty front line demonstration were carried out on 24 ha area. Each FLDs on 0.40 ha area with farmers practices considered as existing farmer practiced for comparison. The data related to the cost of cultivation, production, productivity, gross return and net return were collected as per schedule and analyzed. Result of the present study revealed that higher mean yield in the demonstrations was recorded (17.72 q/ha) as compared to farmers practice (14.12 q/ha) traditionally adopted by the farmers. 25.28 percentage increases in the yield over farmers practice was found. The extension gap, technology gap and technology index were computed $7.28 \mathrm{q} / \mathrm{ha}, 3.60 \mathrm{q} / \mathrm{ha}$ and $29.12 \%$ respectively. The demonstration fields gave higher net return every year. The results of the study indicated the gap exited in the potential yield and demonstration yield is due to soil fertility and weather conditions.

\section{Introduction}

Soybean (Glycine max (L.) Merrill) is generally referred to as golden as well as wonder bean because seeds are rich in oil (20\%) and proteins (40-44\%), amino acids, lysine $(5 \%)$, which is deficient in most of the cereals. In Maharashtra state, soybean crop is grown on an area of 3976000 hectare with total production 4616000 Metric Tons with average productivity of $808 \mathrm{~kg} / \mathrm{h} a$ (Anonymous, 2016). The poor productivity of soybean is mainly due to imbalanced application of nutrients and use of traditional varieties. Under such situations, use soil test base nutrient management and biofertilizer seed treatment had shown advantage in enhancing soybean productivity. Macro nutrients such as nitrogen, phosphorus and potassium play a crucial role in plant growth and yield. Soybean nitrogen requirements are met in a complex manner, as this crop is capable of utilizing both soil $\mathrm{N}$ (mostly in the form of nitrate) and atmospheric $\mathrm{N}$ (through symbiotic nitrogen fixation). Some researchers suggested that $\mathrm{N}$ fertilization is not necessary for inoculated soybean. Whereas, others indicated that $\mathrm{N}$ fertilization 
is necessary to improve yield and quality of soybean depending on application rate. Bodkhe et al., (2014) reported that application of a small amount of $\mathrm{N}$ at planting called as "starter N" reported to beneficial to improve early growth and yield of soybean in most cases. A number of microorganisms are considered as challenging agents for agriculture to promote better nutrient uptake and availability for plant use particularly zinc mobilizing and acidifying culture may help to increase the zinc and other micronutrients availability for the crops like soybean. Since the information on soybean to inoculation with Rhizobium and phosphate solubilizing bacterial inoculants is meager.

The main aim of Krishi Vigyan Kendras is to reduce the time lag between generation of technology at the research institution and its transfer to the farmers for increasing productivity and income from the agriculture and allied sectors on sustained basis. Under front line demonstration (FLDs), introduction of improved technologies/package practices is the one of the mandate of Krishi Vigyan Kendra along with conductance of long-term educational activity in a systematic manner in farmers' fields. In the absence of knowledge of research emanated improved technologies among farmers, it was not feasible to harness the yield potentials of soybean in the state Maharashtra. Hence, Krishi Vigyan Kendra, Hingoli was organized front line demonstration in its six adopted villages with an objective to convince farmers on benefits of improved package of practices on soybean over practices followed by them.

\section{Materials and Methods}

Utilizing the information generated during Participatory Rural Appraisal (PRA), the Krishi Vigyan Kendra, Hingoli, organized 60 front line demonstration (0.4 ha area each) during 2009-2012 and 2013-2015 on soil test based nutrient management (macro and micro nutrients) on farmers' fields in adopted villages viz., Dandegaon, Kumbharwadi, Digras, Sukalivir, yedsi and Bhategaon of Kalamnuri Taluka in HIngoli district of Maharashtra. The study area monsoon starts from the month of June and ends in September. In the remaining period the weather is very dry. The average rainfall in the district is $895 \mathrm{~mm}$. the maximum temperature of the district is 42.6 degree Celsius and minimum temperature are 10.6 degree Celsius. The soil of adopted villages slightly alkali in nature, low to medium organic carbon found, very low to medium range in available phosphorus and high to very high available potassium were occurring.

The packaged of improved practices demonstrated encompassed a new variety (MAUS 71), integrated nutrient management (soil test based) viz., 30:60:30 + 30 Kg Zinc Sulphate kg/ha + Rhizobium + PSB @ 25 $\mathrm{g} / \mathrm{kg}$ seed over existing farmers practices of (local check18:46:00:00 NPKS kg/ha).

Before conducting the demonstrations, training to the farmers of respective villages was imparted with respect to envisaged technological interventions. Site selection, farmers' selection, layout of demonstration and farmers participation were considered as suggested by Choudhury (1999). The observation yield and economic performance of front line demonstration, the data on output were collected from FLDs as well as local plots from all selected farmers and finally the grain yield, cost of cultivation, yield, net returns of different farmers was analyzed by the formula.

Average $=\left(\mathrm{F}_{1}+\mathrm{F}_{2}+\mathrm{F}_{3} \ldots \ldots \ldots . \mathrm{Fn}\right) / \mathrm{N}$

$\mathrm{F} 1=$ Farmer

$\mathrm{N}=$ No. of Farmers 
In the present study, technology index was operationally defined as the technical feasibility obtained due to implementation of Front Line Demonstrations in Soybean. To estimate the technology gap, extension gap and technology index following formula used by Samui et al., Sagar and Chandra (2004) have been used.

Formula as suggested by Samui et al., (2000).

Technology gap $=$ Potential yield Demonstration yield

Extension gap $=$ Demonstration yield Farmers yield

$$
\begin{array}{r}
\text { Potential yield - Demonstration yield } \\
\text { Technology Index }(\%)=\text {--------------- X } 100 \\
\text { Potential yield }
\end{array}
$$

The economic analysis was done by working out cost of cultivation utilizing the inputs prices of commodities which prevailed during five years of demonstration, gross and net returns and benefit cost ratio.

\section{Results and Discussion}

\section{Seed yield}

A comparison of productivity levels between demonstration and framers practices is shown in table 1. It is evident from results that under the improved practice (demonstrated plots), performance of soybean yield was occurring higher than in the local check (farmer practice). Seed yield of Soybean recorded was in range of 12.10 to $21.25 \mathrm{q}$ per ha (average $17.72 \mathrm{q} / \mathrm{ha})$ by adoption of improved packaged of practices (balance fertilizer (soil test based) viz., 30:60:30 + 30 Kg Zinc Sulphate kg/ha + Rhizobium + PSB @ 25 $\mathrm{g} / \mathrm{kg}$ seed) over existing farmers practices of (local check18:46:00:00 NPKS kg/ha), an increase of 14.15 to 33.33 per cent (average
$25.28 \%$ ) in seed yield was recorded during the study period due to improved package of practices. These results are I agreement with findings of Tiwari et al., (2013). It was also observed that the seed yield during Kharif 2014-15 was recorded lower than that of Kharif 2013-14 due to moisture stress during pod formation in the district.

From these results it is evident that the performance of the technology demonstrated was found to be better than the farmers' practice under the same environment conditions. The farmers were motivated by seeing the results in term of productivity and they are adopting the technologies.

\section{Technology gap}

The technology gap were observed during these years and this was lowest $3.75 \mathrm{q} / \mathrm{ha}$ during the 2013-14 and was highest 12.90 $\mathrm{q} / \mathrm{ha}$ 2014-15. On average basis the technology gap of all the sixty demonstration was found to be $7.28 \mathrm{q} / \mathrm{ha}$.

\section{Extension gap}

An extension gap ranging from 1.50 to 5.00 $\mathrm{q} /$ ha was found between FLDs demonstration and farmers practices during the different time line and on average basis the extension gap was found to be $3.6 \mathrm{q} / \mathrm{ha}$ (Table 1). The extension gap was lowest $1.50 \mathrm{q} / \mathrm{ha}$ in the year 2014-15 and was highest $5.00 \mathrm{q} / \mathrm{ha}$ in the year 2009-10. Such gap might be attributed to adoption of improved technology in demonstrations which resulted in higher grain yield than that in the farmers' practices.

\section{Technology index}

The technology index shows the feasibility of the demonstrated technology at the farmers' fields. The technology index varied from 15.00 to $51.60 \%$ (Table 1 ). 
Table.1 Productivity, technology gap, extension gap and technology index of soybean under Front Line Demonstrations on Farmers fields

\begin{tabular}{|c|c|c|c|c|c|c|c|c|c|c|c|}
\hline \multirow[t]{3}{*}{ Year } & \multirow{3}{*}{$\begin{array}{c}\text { Area } \\
\text { (ha) }\end{array}$} & \multirow{3}{*}{$\begin{array}{l}\text { No of } \\
\text { farmers }\end{array}$} & \multicolumn{5}{|c|}{ Grain yield (q/ha) } & \multirow{3}{*}{$\begin{array}{c}\text { Per } \\
\text { cent } \\
\text { increase } \\
\text { over FP }\end{array}$} & \multirow{3}{*}{$\begin{array}{l}\text { Technology } \\
\text { gap (q/ha) }\end{array}$} & \multirow{3}{*}{$\begin{array}{c}\text { Extension } \\
\text { gap } \\
\text { (q/ha) }\end{array}$} & \multirow{3}{*}{$\begin{array}{c}\text { Technolog. } \\
\text { index }(\%)\end{array}$} \\
\hline & & & \multirow[t]{2}{*}{ Potential } & \multicolumn{3}{|c|}{ Recommended Practice } & \multirow{2}{*}{$\begin{array}{l}\text { Farmer } \\
\text { practice }\end{array}$} & & & & \\
\hline & & & & highest & lowest & Average & & & & & \\
\hline $2009-10$ & 4.8 & 12 & 25 & 24.50 & 17.20 & 20.00 & 15.00 & 33.33 & 5.00 & 5.00 & 20.00 \\
\hline $2010-11$ & 4.8 & 12 & 25 & 25.20 & 11.50 & 19.25 & 14.70 & 30.95 & 5.75 & 4.55 & 23.00 \\
\hline $2013-14$ & 4.8 & 12 & 25 & 24.10 & 19.20 & 21.25 & 18.30 & 16.12 & 3.75 & 2.95 & 15.00 \\
\hline $2014-15$ & 4.8 & 12 & 25 & 14.20 & 10.00 & 12.10 & 10.60 & 14.15 & 12.90 & 1.50 & 51.60 \\
\hline Total/mean & 4.8 & 12 & 25 & 21.3 & 14.08 & 17.72 & 14.12 & 25.58 & 7.28 & 3.6 & 29.12 \\
\hline
\end{tabular}

Table. 2 Gross return, cost of cultivation, net return and B: C ratio as affected by improved and local technology under

FLDs on farmers' fields

\begin{tabular}{|c|c|c|c|c|c|c|c|c|c|c|}
\hline \multirow[t]{2}{*}{ Year } & \multirow[t]{2}{*}{$\begin{array}{l}\text { No. of } \\
\text { farmers }\end{array}$} & \multicolumn{2}{|c|}{$\begin{array}{c}\text { Gross expenditure } \\
\text { (Rs./ha) }\end{array}$} & \multicolumn{2}{|c|}{$\begin{array}{l}\text { Grass returns } \\
\text { (Rs./ha) }\end{array}$} & \multicolumn{2}{|c|}{$\begin{array}{l}\text { Net returns } \\
\text { (Rs./ha) }\end{array}$} & \multirow{2}{*}{$\begin{array}{l}\text { Additional } \\
\text { net returns } \\
\text { (Rs./ha) }\end{array}$} & \multicolumn{2}{|c|}{ B:C Ratio } \\
\hline & & $\mathbf{R P}$ & FP & $\mathbf{R P}$ & FP & $\mathbf{R P}$ & FP & & $\mathbf{R P}$ & FP \\
\hline $2009-10$ & 12 & 19601.00 & 15164.00 & 29900.00 & 17000.00 & 10299.00 & 1836.00 & 10494.00 & 1.53 & 1.12 \\
\hline $2010-11$ & 12 & 20571.00 & 18950.00 & 47425.00 & 35310.00 & 26854.00 & 16360.00 & 16350.00 & 2.31 & 1.86 \\
\hline 2011-12 & 12 & 29900.00 & 31450.00 & 59200.00 & 44400.00 & 29300.00 & 12950.00 & 12750.00 & 1.98 & 1.41 \\
\hline 2014-15 & 12 & 27450.00 & 29450.00 & 42350.00 & 37100.00 & 14900.00 & 7650.00 & 8463.00 & 1.54 & 1.26 \\
\hline Total/mean & 12 & 26176.00 & 25983.00 & 51925.00 & 40670.00 & 25749.00 & 14687.00 & 11061.00 & 1.95 & 1.53 \\
\hline
\end{tabular}


On an average technology index was observed 29.12 per cent during the five years of FLDs programme, which shows the efficiency of good performance of technology interventions. This will accelerated the adoption of demonstrated technical intervention to increase the yield performance of soybean.

\section{Economics}

Economics of soybean production under front line demonstrations was recorded and the results of the study have been presented in table 2 . The result of economic analysis of soybean production revealed that front line demonstration recorded higher grass return range from 29900.00 Rs. to (80750.00 Rs. (average 51925.00 Rs.) and net return, 10299.00 Rs. to 47390.00 Rs. (average 25749.00 Rs.) with higher benefit const ratio range 1.53 to 2.42 (average 1.95) due to balance nutrient management ((soil test based) viz., 30:60:30 + 30 Kg Zinc Sulphate kg/ha + Rhizobium + PSB @ 25 $\mathrm{g} / \mathrm{kg}$ seed) as compared to farmer practices were applied (local check18:46:00:00 NPKS kg/ha). These results are in accordance with findings of Dhake et al., (2015) and Hiremath and Nagaraju (2009), further, reduce the cost of cultivation per hector area. In demonstration has increased additional net return $\mathrm{Ra} 11061.00$ averagely per ha. More and less similar results were also reported by Haremath and Nagaraju (2009) and Bhowate and Olambe (2017).

The Front line demonstration produces significant positive results and provided the researcher an opportunity to demonstrate the productivity potential and profitability of the latest technology (intervention) under real forming situation, which they have been advocating for long time. This could be circumventing some of the constraints in the existing transfer of technology system in the district, Hingoli of Maharashtra. The productivity gain under FLDs over existing practices of soybean cultivation created greater awareness and motivated the other farmers to adopt balance nutrients management (base soil test) to increase the nutrient availability and improve productivity.

\section{References}

Anonymous, 2016-17. Economic survey of Maharashtra, Directorate of Economics and Statistics, planning department, government of Maharashtra, Mumbai, PP 113-114.

Bhowate, R.T., and Olambe, A. P. 2017. Nutrient management in wheat through front line demonstration in Hingoli district. J. Krishi Vigyan 2017, 6(1):138-140.

Bodkhe, A.A., Syed Ismail and Javed Jani 2014. Effect of chemical fertilizers and microbial inoculants on soybean (Glycine max L.) safflower (Carthmus tinctorius) cropping pattern. Green farming5 (3): 341-345.

Choudhary B. N., 1999. Krishi Vigyan Kendra -A guide for KVK Managers, Publication of Division of Agricultural Extension, ICAR, PP 73-8.

Dhaka, B. L., Poonia, M.K., Meena, B.S. and Bairwa, R.K. 2015. Yield and economic viability of coriander under front line demonstrations in Bundi district of Rajasthan. J. Hortl. Sci., 1092:226-28.

Hiremath, S.M., Nagarju, M.V. 2009. Evaluation of Frontline demonstration on onion in Haveri district of Karnataka. Karnataka $J$. Agric. Sci., 22(5): 1092-1093.

Sagar, R.L., and Chandra, G. 2004. Evaluation of front line demonstrations on mustard in Sunderbah, West Bengal. Indian J. Exten. Edu, 40: 96-97.

Samui, S.K., Maitra, S., Roy, D. K., Mondal, A.K., and Saha, D 2000. Evaluation on front line demonstration on groundnut (Arachis hypogeal L.). J. Indian Soc. Coastal Agric. Res., 18: 180-183.

\section{How to cite this article:}

Bhowate, R.T., M.B. Dhole and Olambe, A.P. 2017. Impact of Front Line Demonstration on Soybean in Hingoli District of Maharashtra, India. Int.J.Curr.Microbiol.App.Sci. 6(9): 3098-3102. doi: https://doi.org/10.20546/ijcmas.2017.609.381 